\title{
Ciclopirox activates ATR-Chk1 signaling pathway leading to Cdc25A protein degradation
}

\author{
Tao Shen ${ }^{1,2}$, Hongyu Zhou ${ }^{1}$, Chaowei Shang ${ }^{1,2}$, Yan Luo ${ }^{1,3}$, Yang Wu ${ }^{1,3}$ and Shile \\ Huang ${ }^{1,2}$ \\ ${ }^{1}$ Department of Biochemistry and Molecular Biology, Louisiana State University Health Sciences Center, Shreveport, LA, USA \\ ${ }^{2}$ Feist-Weiller Cancer Center, Louisiana State University Health Sciences Center, Shreveport, LA, USA \\ ${ }^{3}$ State Key Laboratory of Biotherapy / Collaborative Innovation Center of Biotherapy, West China Hospital, Sichuan University, \\ Chengdu, Sichuan, P.R. China
}

Correspondence to: Shile Huang, email: shuan1@Isuhsc.edu

Keywords: Ciclopirox; Cdc25A; ATR; Chk1; DNA damage

Received: January 08, $2018 \quad$ Accepted: February 11, $2018 \quad$ Published: February 15, 2018

Copyright: Shen et al. This is an open-access article distributed under the terms of the Creative Commons Attribution License 3.0 (CC BY 3.0), which permits unrestricted use, distribution, and reproduction in any medium, provided the original author and source are credited.

\section{ABSTRACT}

Ciclopirox olamine (CPX), an off-patent anti-fungal drug, has been found to inhibit the $G_{1}$-cyclin dependent kinases partly by increasing the phosphorylation and degradation of Cdc25A. However, little is known about the molecular target(s) of CPX responsible for Cdc25A degradation. Here, we show that CPX induced the degradation of Cdc25A neither by increasing CK1a or decreasing DUB3 expression, nor via activating GSK3 $\beta$, but through activating Chk1 in rhabdomyosarcoma ( $R$ h30) and breast carcinoma (MDA-MB-231) cells. This is strongly supported by the findings that inhibition of Chk1 with TCS2312 or knockdown of Chk1 profoundly attenuated CPXinduced Cdc25A degradation in the cells. Furthermore, we observed that CPX caused DNA damage, which was independent of reactive oxygen species (ROS) induction, but related to iron chelation. CPX treatment resulted in the activation of ataxia telangiectasia mutated (ATM) and ATM-and RAD3-related (ATR) kinases. Treatment with Ku55933 (a selective ATM inhibitor) failed to prevent CPX-induced Chk1 phosphorylation and Cdc25A degradation. In contrast, knockdown of ATR conferred high resistance to CPX-induced Chk1 phosphorylation and Cdc25A degradation. Therefore, the results suggest that CPX-induced degradation of Cdc25A is attributed to the activation of ATR-Chk1 signaling pathway, a consequence of iron chelationinduced DNA damage.

\section{INTRODUCTION}

Ciclopirox olamine (CPX), which has a broad spectrum of action against dermatophytes, yeast, filamentous fungi and bacteria [1], has been widely used for the treatment of superficial fungal infection for over 20 years [2]. Recent studies have implicated that CPX also has potent anticancer activity, by inhibiting cell proliferation and inducing cell death in tumor cells [3-15]. In addition, CPX has been found to inhibit angiogenesis [16], although this remains disputable [17]. Moreover, CPX inhibits lymphangiogenesis [18]. Acute toxicity tests have shown that the oral $\mathrm{LD}_{50}$ values of CPX in rats, mice and rabbits are in the range of $1700-3290 \mathrm{mg} / \mathrm{kg}$ of body weight [19,
20], suggesting that CPX is well tolerated in the animals. Oral administration of CPX at $30 \mathrm{mg} / \mathrm{kg}$ body weight for 4 weeks or at $10 \mathrm{mg} / \mathrm{kg}$ for 3 months has not been found to exhibit obvious toxic symptoms (e.g. gross organ toxicity and body weight loss), in a variety of experimental animals [19], indicating a favorable systematic therapeutic index of CPX. Pharmacokinetics studies have demonstrated that $\sim 10 \mu \mathrm{M}$ serum concentrations of CPX are achievable after repeated administration of CPX to rats and dogs [19], with a half-life $\left(\mathrm{t}_{1 / 2}\right)$ of 6.8-7.6 h [21]. Recently, a phase I clinical trial study has shown that oral administration of CPX at a dose of $40 \mathrm{mg} / \mathrm{m}^{2}$ once daily for 5 days is well tolerated in patients, and induces disease stabilization and/ or hematologic improvement in $2 / 3$ patients with advanced 
hematologic malignancies [22]. Hence, CPX has emerged as a new and promising anticancer agent.

Cyclin-dependent kinases (CDKs) play a key role in the regulation of cell cycle progression, and eventually cell division or cell proliferation [23]. The activities of CDKs are precisely regulated by multiple events such as phosphorylation, dephosphorylation and protein-protein interaction [23], among which, the removal of inhibitory phosphorylation on CDKs by cell division cycle 25 (Cdc25), a dual-specificity protein phosphatase, is critical to full activation of CDKs [23, 24]. Cdc25 family has three members: Cdc25A, Cdc25B, and Cdc25C [25]. Although the catalytic domains of these phosphatases are well conserved, their regulatory domains, which decide their subcellular distribution and turnover, are greatly diverse $[25,26]$. Both $\mathrm{Cdc} 25 \mathrm{~B}$ and $\mathrm{Cdc} 25 \mathrm{C}$ promote $\mathrm{G}_{2} / \mathrm{M}$ progression by primarily dephosphorylating CDK1 at T14/Y15, two inhibitory phosphorylation sites [27], whereas Cdc25A plays a pivotal role in assisting both $\mathrm{G}_{1} / \mathrm{S}$ and $\mathrm{G}_{2} / \mathrm{M}$ progression by dephosphorylating CDK 4 at Y17 [28], CDK6 at Y24 [29], as well as CDK2 and CDK1 at T14/Y15 [30, 31]. As overexpression of Cdc25A predicts the malignancy and poor prognosis in cancer patients [25], Cdc25A has emerged as a new target for cancer therapy. Recent studies have shown that CPX, at high concentrations $(>10 \mu \mathrm{M})$, downregulates the cellular protein expression of cyclins (A, B1, D1 and E) and cyclin-dependent kinases (CDK2 and CDK4), and upregulates the expression of the CDK inhibitor p21 $1^{\text {Cip } 1}$ [5]. However, CPX, at low concentrations $(\leq 5 \mu \mathrm{M})$, drastically reduces the cellular protein level of Cdc25A, which results in increased inhibitory phosphorylation of $\mathrm{G}_{1}-\mathrm{CDKs}$, leading to the accumulation of cells in $\mathrm{G}_{1}$ phase of the cell cycle in tumor cells [32]. Furthermore, CPX neither alters the mRNA level of Cdc25A, nor reduces the protein synthesis of $\mathrm{Cdc} 25 \mathrm{~A}$, but promotes the degradation of Cdc25A [32]. To better understand the molecular mechanism of anticancer action of CPX, it is of great importance to elucidate how CPX induces Cdc25A protein degradation.

The protein degradation of $\mathrm{Cdc} 25 \mathrm{~A}$ is primarily associated with DNA damage [33]. In response to genotoxic stress-induced DNA damage, ataxia telangiectasia mutated (ATM)/ATM-and RAD3-related (ATR)-Chk1/Chk2 cascade is activated, leading to Cdc25A/C degradation $[34,35]$, which stops cell cycle progression, and lets cells repair damaged DNA for survival [36]. Activated Chk1 phosphorylates S76 on Cdc25A, priming the further phosphorylation on S79 and $\mathrm{S} 82$, by casein kinase $1 \alpha(\mathrm{CK} 1 \alpha)$ [37-40]. The phosphorylation of S82 facilitates Cdc25A ubiquitination and subsequent proteasome-mediated degradation [40, 41], inhibiting CDK2 activity [42] and arresting cells at $\mathrm{G}_{1}$ phase of the cell cycle [43]. Besides, S76 residue of Cdc25A can also be phosphorylated by glycogen synthase kinase $3 \beta$ (GSK3 $\beta$ ) [44]. Chk2, another checkpoint protein activated by ATM [45], can phosphorylate $\mathrm{Cdc} 25 \mathrm{~A}$ at $\mathrm{S} 124$, which promotes Cdc25A degradation and downregulates CDK2 activity resulting in blockage of DNA synthesis [45]. This study sought to determine whether CPX-induced phosphorylation and degradation of Cdc25A is through activating CK1 $\alpha$, GSK $3 \beta$, and/or ATM/ ATR-Chk $1 / 2$ in tumor cells.

\section{RESULTS}

\section{CPX-induced Cdc25A degradation is not attributed to increased CK1 $\alpha$ or decreased DUB3 expression}

Our previous study has shown that CPX induces the phosphorylation of Cdc25A on S82, and Cdc25A-S82A mutant is resistant to CPX-induced degradation [32], indicating that the phosphorylation on S82 is essential for CPX-induced Cdc25A degradation. Since CK1 $\alpha$ has been reported to be responsible for phosphorylating $\mathrm{Cdc} 25 \mathrm{~A}$ on S82 [40], and CK1 $\alpha$ is a constitutively active kinase, whose activity is primarily determined by the cellular protein level [46], we reasoned that CPX-induced phosphorylation of Cdc25A (S82) is through upregulating protein expression of CK1 $\alpha$. For this, MDA-MB-231 cells were treated with CPX $(0-20 \mu \mathrm{M})$ for $24 \mathrm{~h}$, followed by Western blot analysis. In line with our previous observation [32], 24-h treatment with CPX downregulated the protein level of Cdc25A in a concentration-dependent manner (Figures 1A and 1B). Surprisingly, CPX did not obviously increase cellular protein expression of CK $1 \alpha$; in fact, at high concentrations (10-20 $\mu \mathrm{M})$ slightly but not significantly downregulated the protein level of CK1 $\alpha$ (Figures 1A and 1B). Therefore, our results ruled out the possibility that CPX promotes Cdc25A degradation by increasing CK1 $\alpha$ expression.

As DUB3, a Cdc25A-specific ubiquitin hydrolase, has been reported to protect $\mathrm{Cdc} 25 \mathrm{~A}$ from degradation by removing conjugated ubiquitin from Cdc25A [47], next, we examined whether CPX promotes Cdc25A degradation by decreasing expression of DUB3. For this, MDAMB-231 cells were treated with CPX $(0-20 \mu \mathrm{M})$ for $24 \mathrm{~h}$, followed by Western blot analysis. As shown in Figures $1 \mathrm{C}$ and 1D, CPX did not reduce the protein level of DUB3. On the contrary, CPX slightly increased the expression of DUB3 in a concentration-dependent manner. Thus, the results suggest that $\mathrm{CPX}$-induced $\mathrm{Cdc} 25 \mathrm{~A}$ degradation is not due to decreased expression of DUB3.

\section{CPX-induced Cdc25A degradation is not due to activation of GSK3ß}

The accumulation of Cdc25A phosphorylation on S82 can also result from the elevation of the 
phosphorylation on correspondent prime residues (e.g. S76) [37]. As GSK3 $\beta$ can phosphorylate Cdc25A on S76 [44], we wondered whether GSK3 $\beta$ is involved in CPXinduced Cdc25A degradation. For this, MDA-MB-231 cells were pretreated for $2 \mathrm{~h}$ with or without $10 \mathrm{mM}$ of $\mathrm{LiCl}$, an inhibitor of GSK3 $\beta$ [48], and then incubated with CPX (0-20 $\mu \mathrm{M})$ for $24 \mathrm{~h}$. As expected, treatment with $\mathrm{LiCl}$ elevated the phosphorylation level of GSK3 $\beta$ (S9) (Lane 7 verse Lane 1, Figure 2A), an inhibitory phosphorylation for $\mathrm{GSK} 3 \beta$ [49]. However, $\mathrm{LiCl}$ pretreatment did not prevent CPX-induced Cdc25A degradation (Figures 2A and 2B). Surprisingly, treatment with CPX alone increased the phosphorylation of GSK3 $\beta$ (S9) (Lanes 2-5 verse Lane 1, Figure 2A), indicating that CPX did not activate but actually inhibited the activity of GSK $3 \beta$. Therefore, it is unlikely that CPX-induced Cdc25A degradation is mediated by GSK3 $\beta$.

\section{CPX-induced Cdc25A degradation is related to activation of Chk1}

As both Chk1 and Chk2 can phosphorylate Cdc25A on multiple residues, promoting SCF-mediated ubiquitination and proteolysis of Cdc25A [39, 45, 5052], next, we asked whether CPX-induced Cdc25A degradation is mediated by Chk1 and/or Chk2. To this end, MDA-MB-231 cells were treated with CPX (0$20 \mu \mathrm{M}$ ) for $24 \mathrm{~h}$, followed by Western blot analysis. As shown in Figures $3 \mathrm{~A}$ and $3 \mathrm{~B}, \mathrm{CPX}(0-20 \mu \mathrm{M})$ treatment increased the phosphorylation on Chk1 (S317 and S345) in a concentration-dependent manner in MDA-MB-231 and Rh30 cells. Particularly, a robust phosphorylation on Chk1 was induced by $10 \mu \mathrm{M}$ of CPX. Of note, treatment with $20 \mu \mathrm{M}$ of $\mathrm{CPX}$ did not result in higher
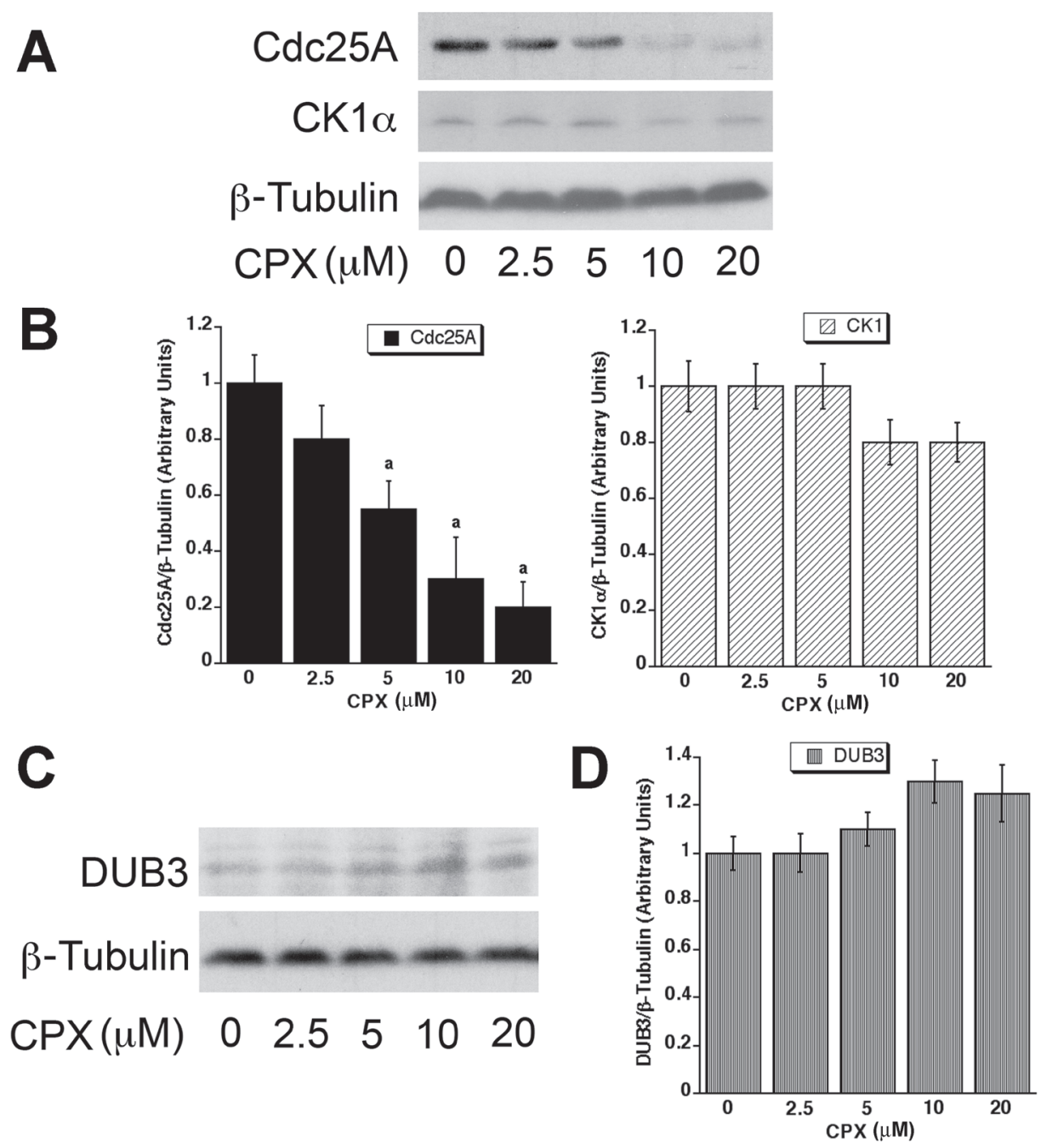

Figure 1: CPX neither upregulates CK1 $\alpha$, nor downregulates DUB3 expression. (A-D) MDA-MB-231 cells were treated with CPX $(0-20 \mu \mathrm{M})$ for $24 \mathrm{~h}$, followed by Western blotting with indicated antibodies. $\beta$-tubulin was used for loading control. Densitometry for the bands in (A) and (C) was performed using NIH ImageJ, as shown in (B) and (D) respectively. Results are the means SE and are pooled from three independent experiments. ${ }^{a}, P<0.05$, difference verse control $(0 \mu \mathrm{M} \mathrm{CPX})$. 
phosphorylation of Chk1, which might be associated with the drastically reduced level of the total Chk1 protein. On the contrary, treatment with CPX did not obviously alter the phosphorylation of Chk2 (T68) in the cells (Figures 3C and 3D). Therefore, the results indicate that Chk1, but not Chk2, is activated in the cells exposed to CPX.

To determine whether activation of Chk1 contributes to CPX-induced Cdc25A degradation, MDA-MB-231 cells were pretreated for $2 \mathrm{~h}$ with or without TCS2312 (250 nM), a selective inhibitor of Chk1 [53], and then incubated with CPX $(0-10 \mu \mathrm{M})$ for $24 \mathrm{~h}$, followed by Western blotting. Consistent with our previous finding [32], CPX (5-10 $\mu \mathrm{M})$ alone obviously downregulated the expression of Cdc25A (Figures 4A and 4B). Interestingly, CPX-induced Cdc25A degradation was remarkably attenuated by TCS2312, suggesting that CPX-induced Cdc25A degradation may be attributed to activation of Chk1.

To confirm the above finding, RNA interference was employed. We found that lentiviral shRNA to Chk1 downregulated the protein expression of Chk1 in MDAMB-231 cells by $\sim 90 \%$, compared with the control shRNA to GFP (Figures 4C and 4D), indicating that the shRNA to Chk1 was working well. As expected, MDA-MB-231 cells infected with the control shRNA to GFP (green fluorescence protein) were sensitive to CPX-induced
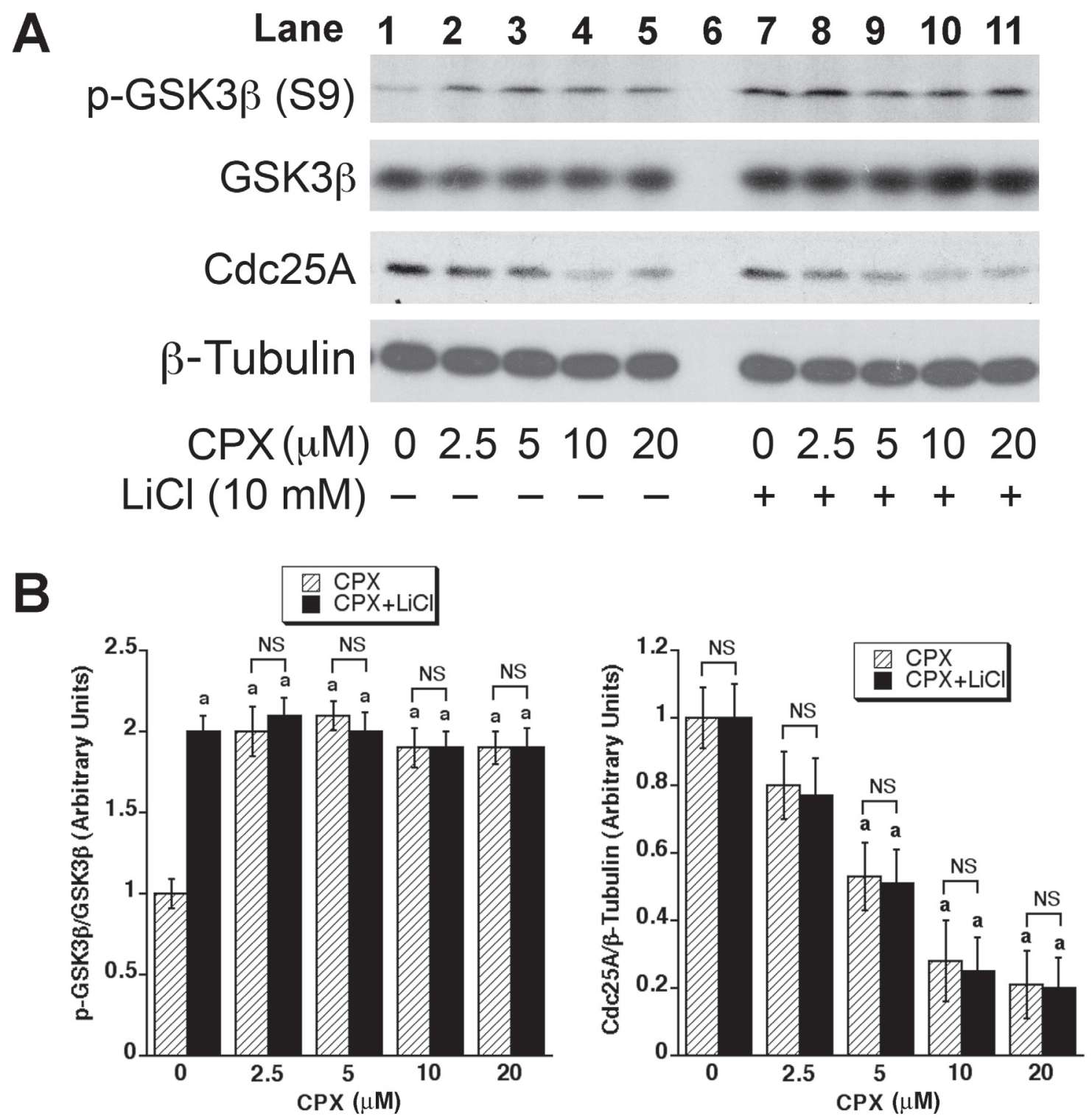

Figure 2: GSK3 $\beta$ is not involved in CPX-induced Cdc25A degradation. (A) MDA-MB-231 cells were pretreated with or without $\mathrm{LiCl}(10 \mu \mathrm{M})$ for $2 \mathrm{~h}$, and then incubated with CPX $(0-20 \mu \mathrm{M})$ for $24 \mathrm{~h}$, followed by Western blotting with indicated antibodies. $\beta$-tubulin was used for loading control. (B) Densitometry for the bands in (A) was performed using NIH ImageJ. Results are the means \pm $\mathrm{SE}$ and are pooled from three independent experiments. ${ }^{a}, P<0.05$, difference verse control ( $\left.0 \mu \mathrm{M} \mathrm{CPX}\right)$. NS, no significance. 
Cdc25A degradation. In contrast, the cells infected with lentiviral shRNA to Chk1 were highly resistant to CPXinduced Cdc25A degradation (Figures 4C and 4D). Taken together, our results demonstrate that CPX induced$\mathrm{Cdc} 25 \mathrm{~A}$ degradation is indeed due to activation of Chk1.

\section{ATR, but not ATM, is involved in mediating CPX- induced $\mathrm{Cdc25} \mathrm{A}$ degradation}

Chk1 can be activated either by ATR in the presence of single-stranded DNA damage [54-56] or by ATM in response to double-stranded DNA damage [57]. Next, we asked whether CPX-induced activation of Chk1 is through ATR and/or ATM. To answer this question, first of all, we checked whether CPX activates ATM and ATR. As shown in Figures 5A and 5B, treatment with $\mathrm{CPX}(5 \mu \mathrm{M})$ for 2-4 h was able to induce remarkable phosphorylation of both ATM and ATR. However, the phosphorylation levels of ATM and ATR declined gradually after 8-h treatment, which was correlated to the decrease in their total protein levels (Figure 5A). Nevertheless, the results indicate that CPX is able to activate both ATR and ATM.

Next, we further determined whether ATM and/ or ATR mediates CPX-induced Cdc25A degradation. For ATM, MDA-MB-231 cells were pretreated for $1 \mathrm{~h}$ with or without Ku55933 $(10 \mu \mathrm{M})$, a selective inhibitor of ATM [58], and then exposed to CPX $(0-20 \mu \mathrm{M})$ for $24 \mathrm{~h}$. We found that CPX $(10-20 \mu \mathrm{M})$ alone dramatically downregulated Cdc25A expression in the cells; Ku55933 pretreatment did not obviously prevent CPX from reducing $\mathrm{Cdc} 25 \mathrm{~A}$ expression (Figures $5 \mathrm{C}$ and $5 \mathrm{D}$ ). The result suggests that ATM is not involved in mediating CPX-induced Cdc25A degradation.

For ATR, MDA-MB-231 cells were pretreated with or without caffeine (2 mM), an ATM/ATR inhibitor [59], for $2 \mathrm{~h}$, and then exposed to CPX $(0-20 \mu \mathrm{M})$ for $24 \mathrm{~h}$, followed by Western blot analysis. As shown in Figures $5 \mathrm{E}$ and $5 \mathrm{~F}$, treatment with $\mathrm{CPX}(0-20 \mu \mathrm{M})$ alone reduced the expression of $\mathrm{Cdc} 25 \mathrm{~A}$ in a concentration-dependent manner, which was blocked by caffeine treatment. Since ATM was found not to be involved in mediating CPXinduced Cdc25A degradation (Figures 5C and 5D), the result implies that CPX promotes $\mathrm{Cdc} 25 \mathrm{~A}$ degradation probably by activation of ATR.

Considering that $2 \mathrm{mM}$ of caffeine may off-target other kinases, to substantiate the role of ATR in mediating Cdc25A degradation, lentiviral shRNA to ATR was used. As shown in Figures $5 \mathrm{G}$ and $5 \mathrm{H}$, lentiviral shRNA to ATR effectively silenced the expression of ATR in MDAMB-231 cells, compared with the control (lentiviral shRNA to GFP). Of interest, knockdown of ATR conferred a high resistance to $\mathrm{CPX}$-induced reduction of $\mathrm{Cdc} 25 \mathrm{~A}$ protein level. Collectively, these results support that ATR, but not ATM, mediates CPX induced-degradation of Cdc25A protein.

\section{CPX induces DNA damage, which is related to} iron chelation, but not ROS induction

As a member of the DNA damage response (DDR) pathway, ATR is frequently activated in response to DNA damage [60]. Hence, we speculated that CPX-induced activation of ATR-Chk1 is associated with DNA damage. To this end, we performed DNA damage analysis. Both MDA-MB-231 and Rh30 cells were treated with CPX (5

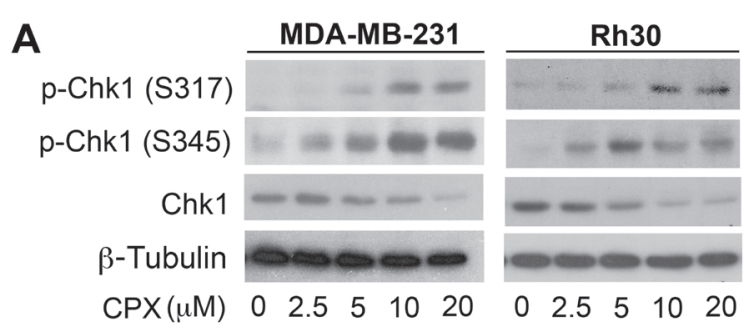

B
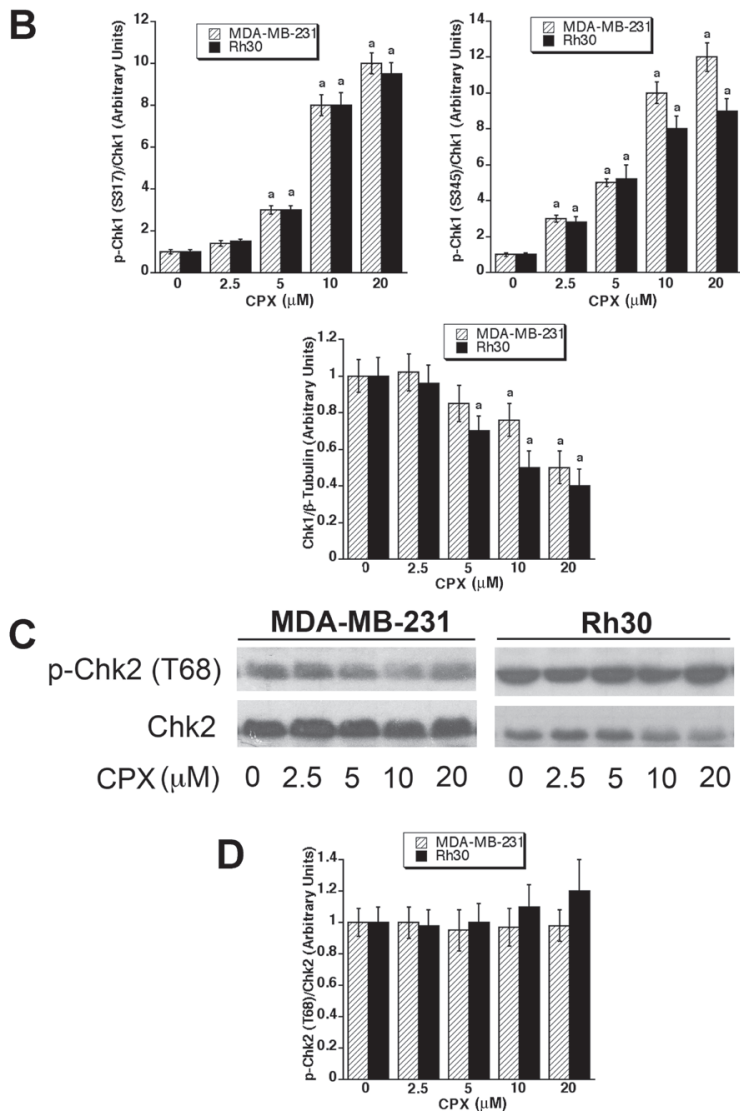

Figure 3: CPX induces activation of Chk1, but not Chk2. (A-D) MDA-MB-231 and Rh30 cells were treated with CPX $(0-20 \mu \mathrm{M})$ for $24 \mathrm{~h}$ and $36 \mathrm{~h}$, respectively, followed by Western blotting with indicated antibodies. $\beta$-tubulin was used for loading control. Densitometry for the bands in (A) and (C) was performed using NIH ImageJ, as shown in (B) and (D), respectively. Results are the means $\pm \mathrm{SE}$ and are pooled from three independent experiments. ${ }^{a}, P<0.05$, difference verse control ( $0 \mu \mathrm{M} \mathrm{CPX})$. 
$\mu \mathrm{M}$ ) for $0-24 \mathrm{~h}$, followed by the comet assay. We found that treatment with CPX $(5 \mu \mathrm{M})$ for 12-24 h significantly increased the number of cells with the comet tail, a marker of DNA damage, compared to the control (Figures 6A and $6 \mathrm{~B})$. The results indicate that $5 \mu \mathrm{M}$ of $\mathrm{CPX}$ is able to cause DNA damage in the cells.

Induction of reactive oxidative species (ROS) is considered a major cause of DNA damage [61]. As we have observed that treatment with CPX can induce ROS in tumor cells [11], next we tested whether CPXinduced DNA damage is related to the induction of ROS. Pretreatment with $5 \mathrm{mM}$ of N-acetyl-L-cysteine (NAC), an antioxidant and ROS scavenger [62], for $2 \mathrm{~h}$, failed to prevent the DNA damage induced by CPX. This is evidenced by the finding that treatment with CPX (0$20 \mu \mathrm{M}$ ) alone induced the phosphorylation on H2AX, a hallmark of DNA damage [63], in a concentrationdependent manner (Figures 6C and 6D). Particularly, at the concentrations of $10-20 \mu \mathrm{M}, \mathrm{CPX}$ was able to induce robust phosphorylation of $\mathrm{H} 2 \mathrm{AX}$. However, pretreatment with NAC did not obviously attenuate CPX-induced phosphorylation of H2AX (Figures 6C and 6D). The results suggest that $\mathrm{CPX}$-induced ROS may not play a dominant role in inducing DNA damage.

Since CPX is an iron chelator [4], and iron chelation can cause DNA damage [64, 65], next, we examined whether CPX causes DNA damage through chelating iron. For this, MDA-MB-231 cells were pretreated with or without ferrous sulfate $(10 \mu \mathrm{M})$ for $1 \mathrm{~h}$, and then exposed to CPX $(0-20 \mu \mathrm{M})$ for $24 \mathrm{~h}$, followed by Western blot analysis. Treatment with CPX $(0-20 \mu \mathrm{M})$ alone elevated the phosphorylation levels of $\mathrm{H} 2 \mathrm{AX}$ and Chk1, as well as reduced the protein level of $\mathrm{Cdc} 25 \mathrm{~A}$ in a concentrationdependent manner. Interestingly, pretreatment with ferrous sulfate remarkably attenuated CPX-induced H2AX/Chk1 phosphorylation and $\mathrm{Cdc} 25 \mathrm{~A}$ degradation (Figures $6 \mathrm{E}$ and $6 \mathrm{~F})$. In addition, pretreatment with ferrous sulfate also blocked CPX-induced DNA laddering (DNA damage) (Figure 6G). The data support the notion that the iron chelation activity of CPX contributes to DNA damage, which activates the DDR pathway, thereby leading to Cdc25A degradation.

\section{DISCUSSION}

CPX, an off-patent fungicide, has been used to treat fungal infection of the skin and nails for $>20$ years [1, 2]. Recently, it has been shown that CPX also possesses potent anti-proliferative effect on tumor cells $[4,5]$. Mechanistically, on one hand, CPX inhibits ribonucleotide reductase (RR), an enzyme that catalyzes the formation of deoxyribonucleotides from ribonucleotides, thus suppressing DNA synthesis [4]. On the other hand, CPX inhibits $\mathrm{G}_{1}-\mathrm{CDKs}$ by downregulating the cellular protein levels of cyclins (A, B1, D1 and E) and cyclin-dependent kinases (CDK2 and CDK4), and upregulating the protein level of the CDK inhibitor (p21 $1^{\text {Cipl }}$ ) [5]. Recently, we have further observed that CPX inhibits $\mathrm{G}_{1}$-CDKs also in part by promoting proteasome-dependent degradation of Cdc25A protein [32]. Here, we present evidence that CPXinduced $\mathrm{Cdc} 25 \mathrm{~A}$ degradation is attributed to activation

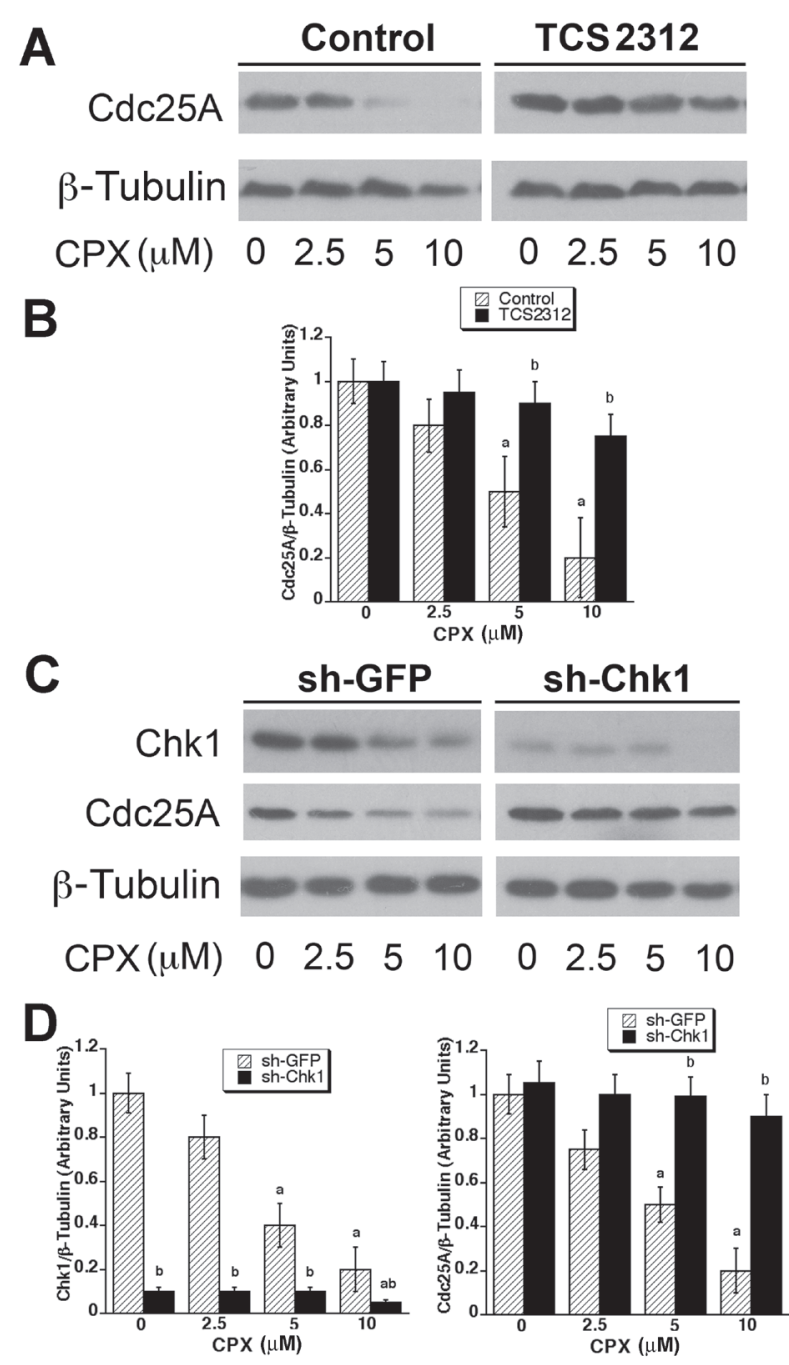

Figure 4: CPX-induced activation of Chk1 links to downregulation of Cdc25A. (A) MDA-MB-231 cells were pretreated with or without TCS2312 $(250 \mathrm{nM})$ for $2 \mathrm{~h}$, and then incubated with CPX $(0-10 \mu \mathrm{M})$ for $24 \mathrm{~h}$, followed by Western blotting with indicated antibodies. $\beta$-tubulin was used for loading control. (B) Densitometry for the bands in (A) was performed using NIH ImageJ. Results are the means \pm SE and are pooled from three independent experiments. ${ }^{a}, P<0.05$, difference verse control $(0 \mu \mathrm{M} \mathrm{CPX}) ;{ }^{b}, P<0.05$, difference between control and TCS2312 treatment. (C) MDA-MB-231 cells, infected with lentiviral shRNA to Chk1 or GFP (control), were incubated with CPX $(0-10 \mu \mathrm{M})$ for $24 \mathrm{~h}$, followed by Western blotting with indicated antibodies. $\beta$-tubulin was used for loading control. (D) Densitometry for the bands in (C) was performed using NIH ImageJ. Results are the means \pm SE and are pooled from three independent experiments. ${ }^{a}, P<0.05$, difference verse control $(0 \mu \mathrm{M} \mathrm{CPX}) ;{ }^{b}, P<0.05$, difference between sh-GFP treatment and sh-Chk1 treatment. 
of ATR-Chk1 pathway, a consequence of iron chelationinduced DNA damage.

Our previous study has shown that Cdc25A-S82A mutant is resistant to $\mathrm{CPX}$-induced degradation [5], suggesting that the elevated phosphorylation on S82 might result in consequent ubiquitination and degradation. Since $\mathrm{S} 82$ of Cdc25A is phosphorylated by $\mathrm{CK} 1 \alpha$ [40], at the beginning, we hypothesized that CPX might upregulate
CK $1 \alpha$ expression. As the cellular protein level of CK $1 \alpha$ determines its activity [46], we directly tested whether CPX increases $\mathrm{CK} 1 \alpha$ protein level. In contrast to our hypothesis, CPX slightly reduced the protein level of CK1 $\alpha$ (Figures $1 \mathrm{~A}$ and 1B). Since Cdc25A degradation is $\beta$-TrCP ubiquitin-dependent $[41,66]$, next, we checked whether CPX downregulates DUB3, a Cdc25A-specific deubiquitinase, which protects $\mathrm{Cdc} 25 \mathrm{~A}$ from degradation
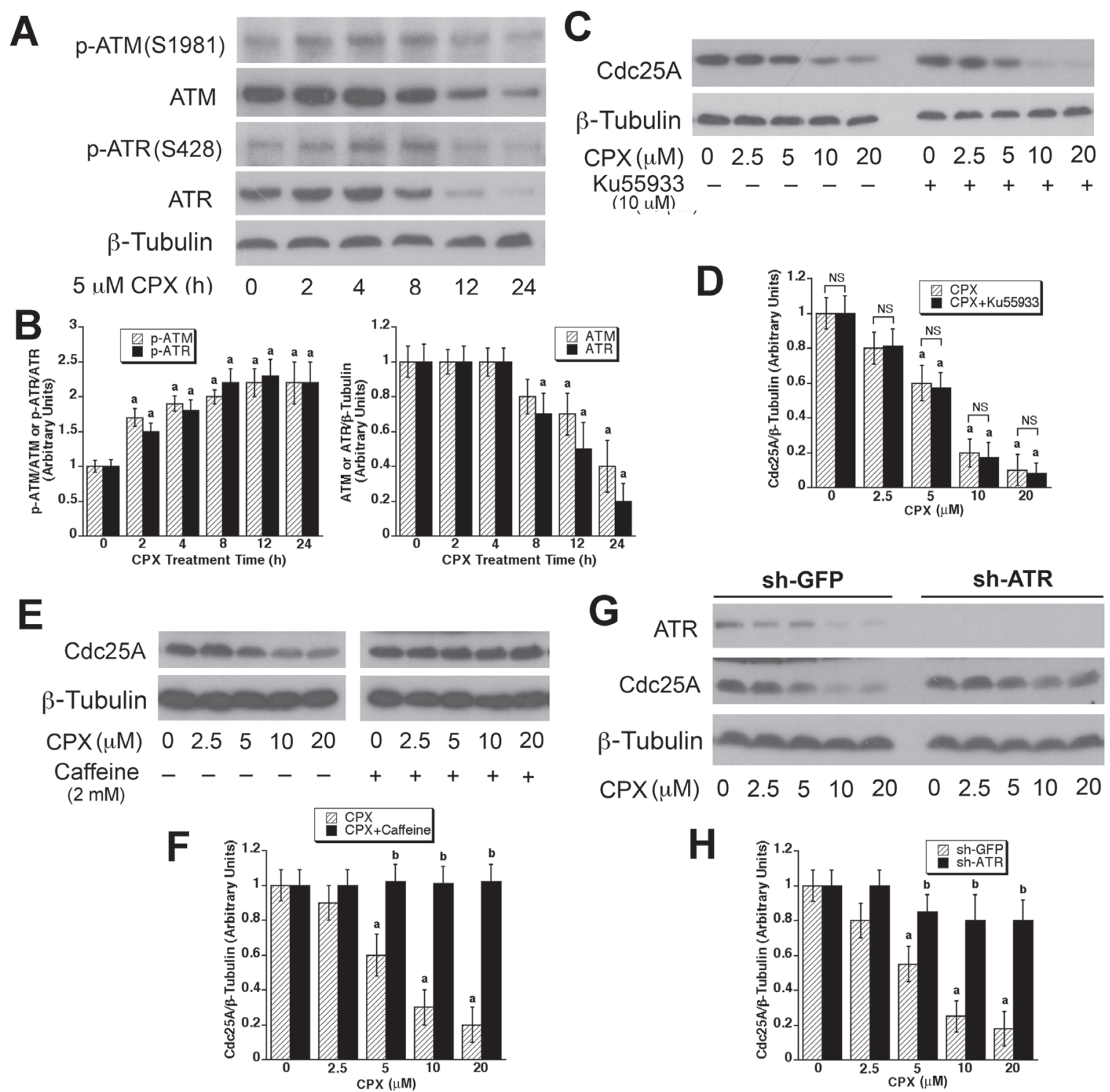

Figure 5: ATR, but not ATM, is involved in CPX-induced Cdc25A degradation. (A) MDA-MB-231 cells were treated with CPX $(5 \mu \mathrm{M})$ for $0-24 \mathrm{~h}$, followed by Western blotting with indicated antibodies. $\beta$-tubulin was used for loading control. (B) Densitometry for the bands in (A) was performed using NIH ImageJ. Results are the means \pm SE and are pooled from three independent experiments. ${ }^{a}$, $P<0.05$, difference verse control (CPX, 0 h). (C-F) MDA-MB-231 cells were pretreated with or without Ku55933 (10 $\mu$ M) $(\mathbf{C})$ or caffeine $(2 \mathrm{mM})(\mathbf{E})$ for $2 \mathrm{~h}$, and then incubated with CPX $(0-20 \mu \mathrm{M})$ for $24 \mathrm{~h}$, followed by Western blotting with indicated antibodies. Densitometry for the bands in $(\mathbf{C})$ and $(\mathbf{E})$ was performed using NIH ImageJ, as shown in (D) and (F), respectively. Results are the means \pm SE and are pooled from three independent experiments. ${ }^{a}, P<0.05$, difference verse control $(0 \mu \mathrm{M}$ CPX). (G) MDA-MB-231 cells, infected with lentiviral shRNA to ATR or GFP (control), were incubated with CPX $(0-20 \mu \mathrm{M})$ for $24 \mathrm{~h}$, followed by Western blotting with indicated antibodies. $\beta$-tubulin was used for loading control. (H) Densitometry for the bands in $(\mathbf{G})$ was performed using NIH ImageJ. Results are the means $\pm \mathrm{SE}$ and are pooled from three independent experiments. ${ }^{a}, P<0.05$, difference verse control $(0 \mu \mathrm{M} \mathrm{CPX}) ;{ }^{b}, P<0.05$, difference between sh-GFP treatment and sh-ATR treatment. 
by removing ubiquitin chain from Cdc25A [47]. Again, CPX did not reduce, but unexpectedly increased DUB3 protein expression slightly (Figures 1C and 1D). Currently, we have no clue why and how CPX downregulated CK $1 \alpha$ and upregulated DUB3 expression. Possibly, this was a cellular response that tried to rescue $\mathrm{Cdc} 25 \mathrm{~A}$ from degradation.
The above observations led us to think about whether CPX induces Cdc25A phosphorylation on S82 by promoting the phosphorylation on a prime residue, reportedly S76 [37]. As S76 can be regulated by GSK3 $\beta$ $[37,44]$ and Chk1 $[39,51]$, we studied whether GSK $3 \beta$ and Chk1 are involved in the regulation of $\mathrm{Cdc} 25 \mathrm{~A}$ expression, in response to $\mathrm{CPX}$ exposure. Using $\mathrm{LiCl}$,
A

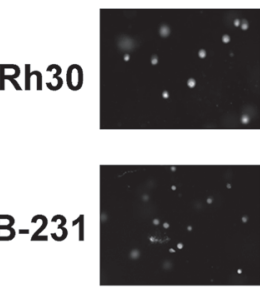

$5 \mu \mathrm{M}$ CPX $\quad 0 \mathrm{~h}$

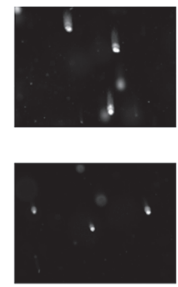

$12 \mathrm{~h}$
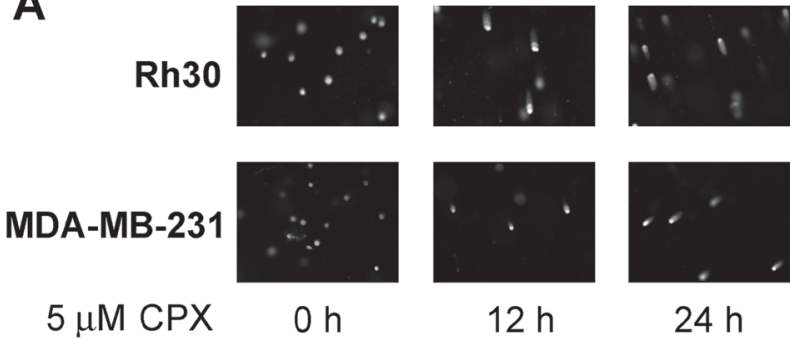

C

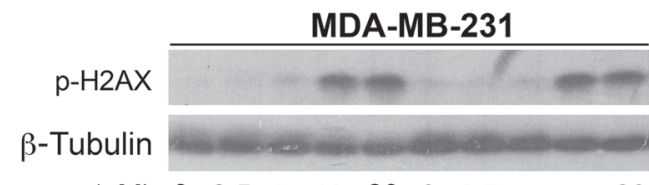

$\mathrm{CPX}(\mu \mathrm{M}) \quad 0 \quad 2.5 \quad 5 \quad 10 \quad 20002.5 \quad 5 \quad 10 \quad 20$

5 mM NAC - - - - + + + + +

E

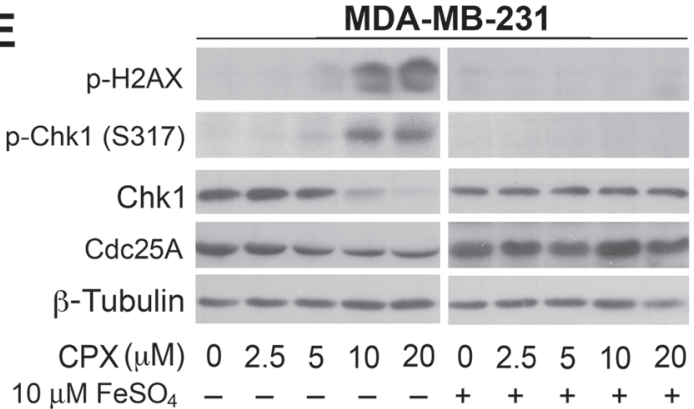

$\mathbf{F}$
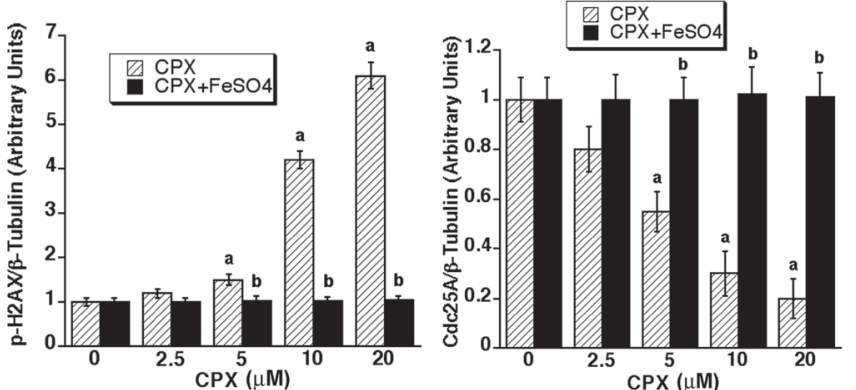
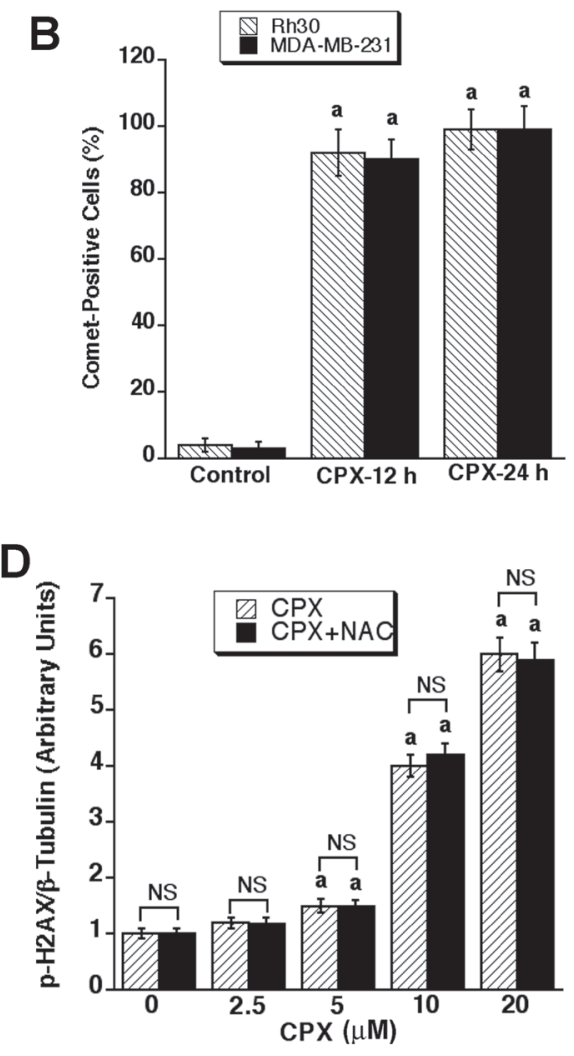

G

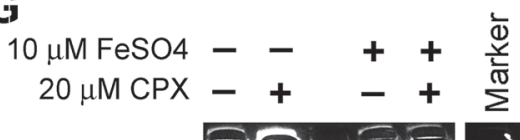

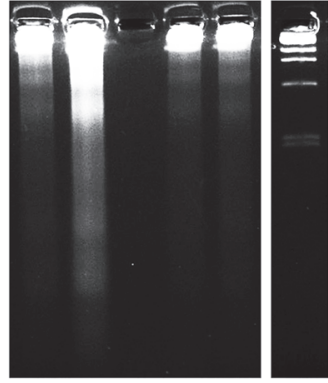

Figure 6: CPX causes DNA damage, which is not related to ROS induction, but due to iron chelation. (A) and (B) Comet assay was performed in MDA-MB-231 and Rh30 cells treated with CPX $(5 \mu \mathrm{M})$ for $0,12 \mathrm{~h}$ and $24 \mathrm{~h}$, respectively. The results were visualized and photographed under a fluorescence microscope at $494 \mathrm{~nm}$ (excitation) and $521 \mathrm{~nm}$ (emission). Representative photos are shown in (A), while quantitative results are illustrated in (B). ${ }^{a}, P<0.05$, difference verse control (CPX, 0 h). (C-G) MDA-MB-231 cells were pretreated with or without NAC $(5 \mathrm{mM})(\mathbf{C})$ or ferrous sulfate $(10 \mu \mathrm{M})(\mathbf{E})$ and $(\mathbf{G})$ for $2 \mathrm{~h}$, and then incubated with $\mathrm{CPX}(0-20 \mu \mathrm{M})$ for $24 \mathrm{~h}$, followed by Western blotting with indicated antibodies $(\mathbf{C})$ and $(\mathbf{E})$ or DNA laddering $(\mathbf{G})$ Densitometry for the bands in $(\mathbf{C})$ and (E) was performed using NIH ImageJ, respectively. Results are the means $\pm \mathrm{SE}$ and are pooled from three independent experiments. ${ }^{a}, P<$ 0.05, difference verse control $(0 \mu \mathrm{M} \mathrm{CPX}) ;{ }^{b}, P<0.05$, difference between $\mathrm{CPX}$ group and $\mathrm{CPX}+\mathrm{FeSO}_{4}$ group. NS, no significance. 
a specific inhibitor of GSK3 $\beta$ [48], we ruled out the involvement of GSK3 $\beta$ (Figure 2). Finally, using pharmacological and genetic inhibition of Chk1 activity, we identified Chk1 as the kinase that was activated by CPX and involved in CPX-induced Cdc25A degradation (Figures 3 and 4). This was substantiated by a further observation that ATR, an upstream kinase of Chk1, was also activated by CPX and involved in CPX-induced Cdc25A degradation (Figure 5). It has been described that activated Chk1 phosphorylates S76 on Cdc25A, priming the further phosphorylation on S79 and S82, by CK $1 \alpha$ [37-40]. The phosphorylation of S82 facilitates Cdc25A ubiquitination and subsequent proteasome-mediated degradation [40, 41], inhibiting CDK2 activity [42] and arresting cells at $\mathrm{G}_{1}$ phase of the cell cycle [43]. Our previous study has shown that CPX treatment induced the phosphorylation of Cdc25A on S76 and S82 [32]. In this study, we did not observe that CPX upregulated the expression of $\mathrm{CK} 1 \alpha$ or triggered the activation of GSK3, but we did discover that CPX induced the activation of ATR-Chk1 pathway. Collectively, our results support the notion that ATR-Chk1 cascade mediates CPX-induced Cdc25A degradation.

It should be mentioned that although our data suggested that the phosphorylation and activation of Chk1 was mainly attributed to CPX-induced ATR activation, we still cannot rule out other possibilities. For instance, PP2A (protein phosphatase 2A), a serine/threonine protein phosphatase, is capable of dephosphorylating Chk1 [67]. Of importance, PP2A activity depends on cellular iron level [68]. CPX is a well-known iron chelator [4], so we deduce that CPX may inhibit PP2A activity. Further research is needed to address whether PP2A plays a role in CPX-induced Chk1 activation, and Cdc25A degradation.

The cross-identification with the DNA laddering and the comet assay confirmed that CPX was able to cause DNA damage, rationalizing the activation of DDR pathway. During the course of studying how CPX causes the DNA damage, we first thought of ROS, since CPX is able to induce ROS [11], and induction of ROS is a major cause of DNA damage [61]. However, to our surprise, CPX-induced DNA damage was not due to

\section{CPX}

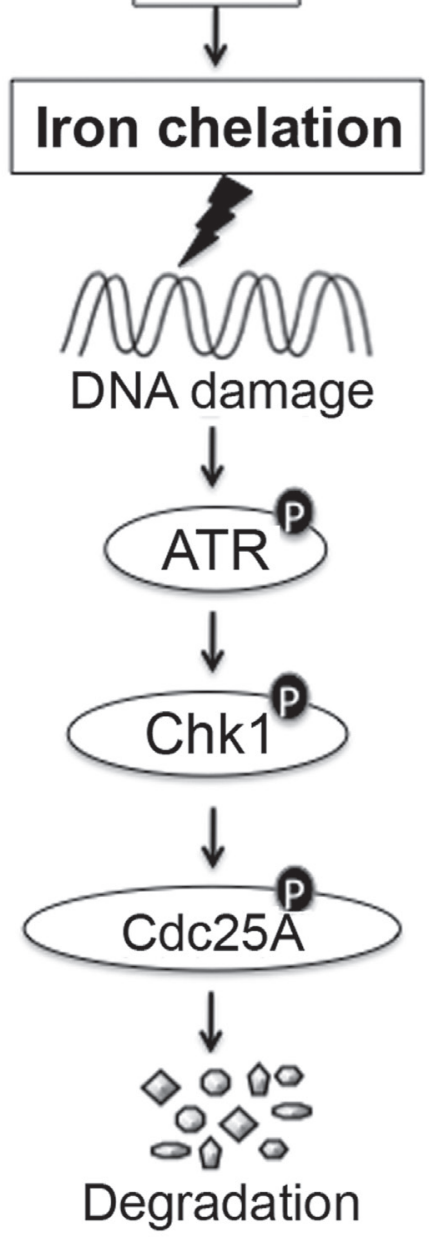

Figure 7: A model of CPX-induced Cdc25A degradation. 
induction of ROS, as NAC, a ROS scavenger, did not have obvious protective effect (Figures 6C and 6D). Instead, CPX caused the DNA damage through its iron chelation activity. This is strongly supported by the finding that addition of ferrous sulfate blocked CPX-induced DNA damage (Figures 6E-6G). A new question from this work is how the iron chelation causes DNA damage. A previous report has shown that RR, an iron-dependent dNTP (deoxynucleotide triphosphates) generator, mediates the genotoxicity of CPX [64]. However, a very high concentration of CPX $(100 \mu \mathrm{M})$ was used in that study, which was in great contrast to low concentrations (5-20 $\mu \mathrm{M})$ of CPX we used here. Nevertheless, a recent study has shown that treatment with 24-h exposure to CPX (5$10 \mu \mathrm{M}$ ) can inhibit RR activity in leukemia (MDAY-D2) cells [4]. Hence, the RR is a possible candidate that may mediate the CPX-caused DNA damage, which could be blocked by addition of $\mathrm{FeSO}_{4}$. We have already tested whether addition of dNTP, a major product of RR, could attenuate CPX-caused DNA damage. However, addition of dNTP failed to prevent CPX-induced damage. We do not know whether this was due to poor membrane transportation efficiency of dNTP in our cell culture model. In the future, an alternative approach is to examine whether overexpression of M1/M2 subunits (RR) attenuates CPX-induced DNA damage, ATR-Chk1 activation, Cdc25A turnover, cell cycle progression, and apoptosis.

In conclusion, here we have shown that CPX induced Cdc25A degradation neither by increasing CK $1 \alpha$ or decreasing DUB3 expression, nor via activating GSK3 $\beta$ in rhabdomyosarcoma $(\mathrm{Rh} 30)$ and breast carcinoma (MDA-MB-231) cells. Instead, CPX-induced Cdc25A degradation was associated with the activation ATRChk1 cascade, resulted from iron chelation-induced DNA damage (Figure 7). The findings shed new light on the molecular mechanism by which CPX inhibits cancer cell proliferation.

\section{MATERIALS AND METHODS}

\section{Materials}

Ciclopirox olamine (CPX) (Sigma, St. Louis, MO, USA) was dissolved in $100 \%$ ethanol to prepare stock solutions $(2.5,5,10$, and $20 \mathrm{mM})$, then aliquoted and stored at $-20^{\circ} \mathrm{C}$. RPMI 1640, Dulbecco's Modified Eagle Medium (DMEM), DMEM/F-12 and 0.05\% Trypsin-EDTA were purchased from Mediatech (Herndon, VA, USA). Fetal bovine serum (FBS) was from Atlanta Biologicals (Lawrenceville, GA, USA). Enhanced chemiluminescence solution was obtained from PerkinElmer Life Science (Boston, MA, USA). The following primary antibodies were used, including those against Cdc25A, Chk1, p-Chk1 (S345), Chk2, p-Chk2 (T68), CK1 $\alpha$, GSK3 $\beta$ (Santa Cruz Biotechnology, Santa Cruz, CA, USA), DUB3 (Abcam, Cambridge, MA, USA), p-GSK3ß (S9), p-Chk1 (S317), ATM, p-ATM (S1981), ATR, p-ATR (S428), p-H2AX (S139) (Cell Signaling, Danvers, MA, USA), and $\beta$-tubulin (Sigma). Goat antimouse IgG-horseradish peroxidase (HRP) and goat antirabbit IgG-HRP were purchased from Pierce (Rockland, IL, USA). All other chemicals were obtained from Sigma (St. Louis, MO), unless stated elsewhere.

\section{Cell culture}

Human rhabdomyosarcoma (Rh30) cell line was described [32] and grown in antibiotic-free RPMI 1640 medium supplemented with 10\% FBS. Human breast adenocarcinoma (MDA-MB-231) cell line (American Type Culture Collection, Manassas, VA) was grown in antibiotic-free DMEM/F12 supplemented with 10\% FBS. 293 TD cells were cultured in DMEM containing 10\% heat-inactivated FBS, as described [69]. All cell lines were cultured in a humidified incubator $\left(37^{\circ} \mathrm{C}\right.$ and $\left.5 \% \mathrm{CO}_{2}\right)$.

\section{Lentiviral shRNAs to Chk1 and ATR and infection}

Plasmids encoding shRNAs to human Chk1 (sc-29269-SH) and human ATR (sc-44284-SH) were purchased from Santa Cruz Biotechnology (Santa Cruz, CA). The plasmids were amplified in TOP 10 competent cells (Invitrogen, Carlsbad, CA, USA) and extracted with Qiagen Plasmid Midi Kit (Qiagen, Valencia, CA, USA). Finally, lentiviral particles were produced in 293TD cells by co-transfection with shRNA to ATR or Chk1 (10 $\mu \mathrm{g})$, together with PMD2.0 (3 $\mu \mathrm{g})$ and psPAX2 (7 $\mu \mathrm{g})$, as described previously [69]. Cells were seeded in 6-well plates at a density of $1 \times 10^{5}$ per well and cultured under normal condition overnight. The cells were then infected with infection solution (fresh medium : lentiviral particle $=$ $1: 1, \mathrm{v} / \mathrm{v}$, plus $5 \mu \mathrm{M}$ polybrene) and cultured under normal condition. After 12-24 h, the cells were re-infected with the above infection solution and cultured overnight under normal condition. Next, the virus-containing medium was replaced with fresh growth medium containing puromycin $(5 \mu \mathrm{g} / \mathrm{ml})$ for selection of infected cells. After culture for 4 days, the selected cells were used for experiments.

\section{Western blotting}

Cells were briefly rinsed with ice-cold phosphate buffered saline (PBS) and lysed, followed by Western blotting as described previously [32]. NIH ImageJ was used for semi-quantitative analysis of the intensities of the bands. 


\section{DNA laddering}

DNA laddering was performed as described [70]. Briefly, MDA-MB-231 cells, grown in 6-well plates $(5 \times$ $10^{5}$ cells/well), were treated with pretreated with/without $10 \mu \mathrm{M}$ of ferrous sulfate $\left(\mathrm{FeSO}_{4}\right)$ for $1 \mathrm{~h}$, and then treated with/without $20 \mu \mathrm{M}$ of CPX for $24 \mathrm{~h}$. Both floating and attached cells were harvested, washed with ice-cold $1 \times$ PBS, and treated with the lysis buffer $(50 \mathrm{mM}$ Tris, $\mathrm{pH}$ 8.0, containing $0.5 \%$ Triton X-100 and $200 \mathrm{mM}$ EDTA) $(200 \mu \mathrm{l} / \mathrm{well})$ on ice for $20 \mathrm{~min}$. After centrifuging at $12,000 \mathrm{rpm}$ for $30 \mathrm{~min}$ at $4^{\circ} \mathrm{C}$, the supernatants were transferred into new Eppendorf tubes, and mixed with the same volume of phenol:chloroform:isoamyl alcohol (25:24:1, v/v) (Invitrogen) for $5 \mathrm{~min}$. Following centrifugation (12,000 rpm, $10 \mathrm{~min}, 4 \mathrm{C})$, the supernatants were transferred to new tubes, mixed with half volumes of ammonium acetate $(10 \mathrm{M})$ and $2.5 \times$ volumes of cold ethanol $\left(-20^{\circ} \mathrm{C}\right)$, and then incubated at $-20^{\circ} \mathrm{C}$ overnight. After centrifuging at $16,000 \mathrm{rpm}$ for $10 \mathrm{~min}$, the supernatants were carefully discarded, and the precipitates were resuspended in $20 \mu \mathrm{l}$ of TE buffer-RNase A solution to dissolve DNA $\left(37^{\circ} \mathrm{C}\right.$ for $\left.30 \mathrm{~min}\right)$. The concentration of the extracted DNA was quantified by NanoDrop 1000 (Nano Drop, Wilmington, DE, USA). The DNA samples were separated onto a $2 \%$ agarose gel (containing $0.5 \mu \mathrm{g} /$ $\mathrm{ml}$ ethidium bromide) in TBE running buffer. The images were visualized and captured with a UV transilluminator equipped with a digital camera.

\section{Comet assay}

Comet assay was conducted as described [71]. Briefly, low melting point agarose $(0.5 \mathrm{~g}$ in $50 \mathrm{ml}$ PBS) was put in a $100-\mathrm{ml}$ glass bottle (cap loosened), and incubated in a beaker containing boiling water until the agarose was melted. The bottle was then placed in a $37^{\circ} \mathrm{C}$ water bath for at least $20 \mathrm{~min}$ to cool down the agarose. Subsequently, freshly trypsinized cells $\left(1 \times 10^{5} / \mathrm{ml}\right)$ were mixed with the melted agarose $\left(\right.$ at $\left.37^{\circ} \mathrm{C}\right)$ at a ratio of $1: 10$ $(\mathrm{v} / \mathrm{v})$, and $50 \mu \mathrm{l}$ of the mixture was immediately pipetted onto 96-well CometSlide ${ }^{\mathrm{TM}}$ (Trevigen, Gaithersburg, $\mathrm{MD}$, USA). After placing the slides flat at $4^{\circ} \mathrm{C}$ in the dark for 10-30 $\mathrm{min}$, the slides were immersed in pre-chilled Lysis Solution (Trevigen) and left at $4^{\circ} \mathrm{C}$ for $1 \mathrm{~h}$. Next, the slides were removed from the Lysis Solution, and immersed in pre-chilled 1 Tris/Borate/EDTA (TBE) buffer at $4^{\circ} \mathrm{C}$ for $30 \mathrm{~min}$. Then, the slides were aligned equally distant from electrodes. Subsequently, $1 \times$ TBE buffer was added not to exceed $0.5 \mathrm{~cm}$ above the slides, followed by electrophoresis (at 1 volt per $\mathrm{cm}$ ). After electrophoresis, the slides were immersed in distilled water for $5 \mathrm{~min}$ at room temperature, and then in $70 \%$ ethanol for $30 \mathrm{~min}$ at room temperature. After the slides were air-dried at room temperature for $10-15 \mathrm{~min}, 100 \mu \mathrm{l}$ of diluted SYBR
Green I was placed onto each sample and incubated for $30 \mathrm{~min}$. Next, the slides were completely dried at room temperature in the dark. Finally, the slides were visualized and photographed under a Nikon epifluorescence microscope at $494 \mathrm{~nm}$ (excitation) and $521 \mathrm{~nm}$ (emission).

\section{Statistical analysis}

Results were expressed as mean values \pm standard errors (mean $\pm \mathrm{SE}$ ). The data were analyzed by one-way analysis of variance (ANOVA) followed by post-hoc Dunnett's $t$-test for multiple comparisons. A level of $P<$ 0.05 was considered to be statistically significant.

\section{Abbreviations}

ATM, ataxia telangiectasia mutated; ATR, ATMand RAD3-related; Cdc25A, cell division cycle $25 \mathrm{~A}$; CDK, cyclin-dependent kinase; CK1 $\alpha$, casein kinase $1 \alpha$; CPX, ciclopirox olamine; DDR, DNA damage response; DMEM, Dulbecco's Modified Eagle Medium; dNTP; deoxynucleotide triphosphates; FBS, fetal bovine serum; GFP, green fluorescence protein; GSK3 $\beta$, glycogen synthase kinase $3 \beta$; NAC, N-acetyl-L-cysteine; PBS, phosphate buffered saline; ROS, reactive oxygen species; PP2A, protein phosphatase 2A; RR, ribonucleotide reductase

\section{GRANT SUPPORT}

This work was supported in part by National Institutes of Health (CA115414; S. Huang), American Cancer Society (RSG-08-135-01-CNE; S. Huang), and Carroll Feist Predoctoral Fellowship Awards (T. Shen and C. Shang), Feist-Weiller Cancer Center, Louisiana State University Health Sciences Center in Shreveport, LA.

\section{CONFLICTS OF INTEREST}

No conflicts of interest were disclosed.

\section{REFERENCES}

1. Subissi A, Monti D, Togni G, Mailland F. Ciclopirox: recent nonclinical and clinical data relevant to its use as a topical antimycotic agent. Drugs. 2010; 70: 2133-52.

2. Shen T, Huang S. Repositioning the Old Fungicide Ciclopirox for New Medical Uses. Curr Pharm Des. 2016; 22: 4443-50.

3. Hoffman BD, Hanauske-Abel HM, Flint A, Lalande M. A new class of reversible cell cycle inhibitors. Cytometry. 1991; 12: 26-32.

4. Eberhard Y, McDermott SP, Wang X, Gronda M, Venugopal A, Wood TE, Hurren R, Datti A, Batey RA, Wrana J, 
Antholine WE, Dick JE, Schimmer AD. Chelation of intracellular iron with the antifungal agent ciclopirox olamine induces cell death in leukemia and myeloma cells. Blood. 2009; 114: 3064-73.

5. Zhou H, Shen T, Luo Y, Liu L, Chen W, Xu B, Han X, Pang J, Rivera CA, Huang S. The antitumor activity of the fungicide ciclopirox. Int J Cancer. 2010; 127: 2467-77.

6. Kim Y, Schmidt M, Endo T, Lu D, Carson D, SchmidtWolf IG. Targeting the Wnt/beta-catenin pathway with the antifungal agent ciclopirox olamine in a murine myeloma model. In Vivo. 2011; 25: 887-93.

7. Song S, Christova T, Perusini S, Alizadeh S, Bao RY, Miller BW, Hurren R, Jitkova Y, Gronda M, Isaac M, Joseph B, Subramaniam R, Aman A, Chau A, Hogge DE, Weir SJ, Kasper J, Schimmer AD, Al-awar R, Wrana JL, Attisano L. Wnt inhibitor screen reveals iron dependence of $\beta$-catenin signaling in cancers. Cancer Res. 2011; 71: 7628-39.

8. Ma TC, Langley B, Ko B, Wei N, Gazaryan IG, Zareen N, Yamashiro DJ, Willis DE, Ratan RR. A screen for inducers of p21waf1/cip1 identifies HIF prolyl hydroxylase inhibitors as neuroprotective agents with antitumor properties. Neurobiol Dis. 2013; 49: 13-21.

9. Sen S, Hassane DC, Corbett C, Becker MW, Jordan CT, Guzman ML. Novel mTOR inhibitory activity of ciclopirox enhances parthenolide antileukemia activity. Exp Hematol. 2013; 41: 799-807.

10. Mémin E, Hoque M, Jain MR, Heller DS, Li H, Cracchiolo B, Hanauske-Abel HM, Pe'ery T, Mathews MB. Blocking eIF5A modification in cervical cancer cells alters the expression of cancer-related genes and suppresses cell proliferation. Cancer Res. 2014; 74: 552-62.

11. Zhou H, Shen T, Shang C, Luo Y, Liu L, Yan J, Li Y, Huang S. Ciclopirox induces autophagy through reactive oxygen species-mediated activation of JNK signaling pathway. Oncotarget. 2014; 5: 10140-50.

12. Sidarovich V, Adami V, Gatto P, Greco V, Tebaldi T, Tonini GP, Quattrone A. Translational downregulation of HSP90 expression by iron chelators in neuroblastoma cells. Mol Pharmacol. 2015; 87: 513-24.

13. Zhou H, Shang C, Wang M, Shen T, Kong L, Yu C, Ye Z, Luo Y, Liu L, Li Y, Huang S. Ciclopirox olamine inhibits mTORC1 signaling by activation of AMPK. Biochem Pharmacol. 2016; 116: 39-50.

14. Shen T, Shang C, Zhou H, Luo Y, Barzegar M, Odaka Y, Wu Y, Huang S. Ciclopirox inhibits cancer cell proliferation by suppression of Cdc25A. Genes Cancer. 2017; 8: 505-16.

15. Yang J, Milasta S, Hu D, AlTahan AM, Interiano RB, Zhou J, Davidson J, Low J, Lin W, Bao J, Goh P, Nathwani AC, Wang R, Wang Y, Ong SS, Boyd VA, Young B, Das S, Shelat A, Wu Y, Li Z, Zheng JJ, Mishra A, Cheng Y, Qu C, Peng J, Green DR, White S, Guy RK, Chen T, Davidoff AM. Targeting histone demethylases in MYC-driven neuroblastomas with ciclopirox. Cancer Res. 2017; 77: 4626-38.
16. Clement PM, Hanauske-Abel HM, Wolff EC, Kleinman HK, Park MH. The antifungal drug ciclopirox inhibits deoxyhypusine and proline hydroxylation, endothelial cell growth and angiogenesis in vitro. Int J Cancer. 2002; 100: 491-8.

17. Linden T, Katschinski DM, Eckhardt K, Scheid A, Pagel H, Wenger RH. The antimycotic ciclopirox olamine induces HIF-1 $\alpha$ stability, VEGF expression, and angiogenesis. FASEB J. 2003; 17:761-3.

18. Luo Y, Zhou H, Liu L, Shen T, Chen W, Xu B, Han X, Zhang F, Scott RS, Alexander JS, Alam A, Huang S. The fungicide ciclopirox inhibits lymphatic endothelial cell tube formation by suppressing VEGFR-3-mediated ERK signaling pathway. Oncogene. 2011; 30: 2098-107.

19. Alpermann HG, Schutz E. Studies on the pharmacology and toxicology of ciclopiroxolamine. Arzneimittelforschung. 1981; 31: 1328-32.

20. Weir SJ, Patton L, Castle K, Rajewski L, Kasper J, Schimmer AD. The repositioning of the anti-fungal agent ciclopirox olamine as a novel therapeutic agent for the treatment of haematologic malignancy. J Clin Pharm Ther. 2011; 36:128-34.

21. Kellner HM, Arnold C, Christ OE, Eckert HG, Herok J, Hornke I, Rupp W. Pharmacokinetics and biotransformation of the antimycotic drug ciclopiroxolamine in animals and man after topical and systemic administration. Arzneimittelforschung. 1981; 31: 1337-53.

22. Minden MD, Hogge DE, Weir SJ, Kasper J, Webster DA, Patton L, Jitkova Y, Hurren R, Gronda M, Goard CA, Rajewski LG, Haslam JL, Heppert KE, Schorno K, Chang H, Brandwein JM, Gupta V, Schuh AC, Trudel S, Yee KW, Reed GA, Schimmer AD. Oral ciclopirox olamine displays biological activity in a phase I study in patients with advanced hematologic malignancies. Am J Hematol. 2014; 89: 363-8.

23. Malumbres M, Barbacid M. Cell cycle, CDKs and cancer: a changing paradigm. Nature Rev Cancer. 2009; 9: 153-66.

24. Sherr CJ, Beach D, Shapiro GI. Targeting CDK4 and CDK6: From Discovery to Therapy. Cancer Discov. 2016; 6: 353-67.

25. Boutros R, Lobjois V, Ducommun B. Cdc25 phosphatases in cancer cells: key players? Good targets? Nat Rev Cancer. 2007; 7: 495-507.

26. Rudolph J. Inhibiting transient protein-protein interactions: lessons from the $\mathrm{Cdc} 25$ protein tyrosine phosphatases. Nat Rev Cancer. 2007; 7: 202-11.

27. Lindqvist A, Rodriguez-Bravo V, Medema RH. The decision to enter mitosis: feedback and redundancy in the mitotic entry network. J Cell Biol. 2009; 185: 193-202.

28. Terada Y, Tatsuka M, Jinno S, Okayama H. Requirement for tyrosine phosphorylation of CDK4 in G1 arrest induced by ultraviolet irradiation. Nature. 1995; 376: 358-62.

29. Iavarone A, Massagué J. Repression of the CDK activator Cdc25A and cell-cycle arrest by cytokine TGF-beta in cells 
lacking the CDK inhibitor p15. Nature. 1997; 387: 417-22.

30. Gautier J, Solomon MJ, Booher RN, Bazan JF, Kirschner MW. Cdc25 is a specific tyrosine phosphatase that directly activates p34cdc2. Cell. 1991; 67: 197-211.

31. Gu Y, Rosenblatt J, Morgan DO. Cell cycle regulation of CDK2 activity by phosphorylation of Thr160 and Tyr15. EMBO J. 1992; 11: 3995-4005.

32. Shen T, Shang C, Zhou H, Luo Y, Barzegar M, Odaka Y, Wu Y, Huang S. Ciclopirox inhibits cancer cell proliferation by suppression of Cdc25A. Genes Cancer. 2017; 8: 505-16.

33. Mailand N, Falck J, Lukas C, Syljuâsen RG, Welcker M, Bartek J, Lukas J. Rapid destruction of human Cde25A in response to DNA damage. Science. 2000; 288: 1425-9.

34. Abraham RT. Cell cycle checkpoint signaling through the ATM and ATR kinases. Genes Dev. 2001; 15: 2177-96.

35. Bartek J, Lukas J. Chk1 and Chk2 kinases in checkpoint control and cancer. Cancer Cell. 2003; 3: 421-29.

36. Zhou BB, Elledge SJ. The DNA damage response: putting checkpoints in perspective. Nature. 2000; 408: 433-9.

37. Donzelli M, Busino L, Chiesa M, Ganoth D, Hershko A, Draetta GF. Hierarchical order of phosphorylation events commits Cdc25A to $\beta$ TrCP-dependent degradation. Cell Cycle. 2004; 3:469-471.

38. Goloudina A, Yamaguchi H, Chervyakova DB, Appella E, Fornace AJ Jr, Bulavin DV. Regulation of human Cdc25A stability by Serine 75 phosphorylation is not sufficient to activate a S phase checkpoint. Cell Cycle. 2003; 2:473-8.

39. Hassepass I, Voit R, Hoffmann I. Phosphorylation at serine 75 is required for UV-mediated degradation of human Cdc25A phosphatase at the S-phase checkpoint. J Biol Chem. 2003; 278: 29824-9.

40. Honaker Y, Piwnica-Worms H. Casein kinase 1 functions as both penultimate and ultimate kinase in regulating $\mathrm{Cdc} 25 \mathrm{~A}$ destruction. Oncogene. 2010; 29: 3324-34.

41. Busino L, Donzelli M, Chiesa M, Guardavaccaro D, Ganoth D, Dorrello NV, Hershko A, Pagano M, Draetta GF. Degradation of Cdc25A by $\beta$-TrCP during $S$ phase and in response to DNA damage. Nature. 2003; 426: 87-91.

42. Blomberg I, Hoffmann I. Ectopic expression of Cdc25A accelerates the G1/S transition and leads to premature activation of cyclin E- and cyclin A-dependent kinases. Mol Cell Biol. 1999; 19: 6183-94.

43. Xiao Z, Chen Z, Gunasekera AH, Sowin TJ, Rosenberg SH, Fesik S, Zhang H. Chk1 mediates S and G2 arrests through Cdc25A degradation in response to DNA-damaging agents. J Biol Chem. 2003; 278: 21767-73.

44. Kang T, Wei Y, Honaker Y, Yamaguchi H, Appella E, Hung MC, Piwnica-Worms H. GSK-3 $\beta$ targets Cdc25A for ubiquitin-mediated proteolysis, and GSK-3 $\beta$ inactivation correlates with Cdc25A overproduction in human cancers. Cancer Cell. 2008; 13: 36-47.

45. Falck J, Mailand N, Syljuåsen RG, Bartek J, Lukas J. The ATM-Chk2-Cdc25A checkpoint pathway guards against radioresistant DNA synthesis. Nature. 2001; 410: 842-7.
46. Knippschild U, Gocht A, Wolff S, Huber N, Löhler J, Stöter M. The casein kinase 1 family: participation in multiple cellular processes in eukaryotes. Cell Signal. 2005; 17: 67589.

47. Pereg Y, Liu BY, O'Rourke KM, Sagolla M, Dey A, Komuves L, French DM, Dixit VM. Ubiquitin hydrolase Dub3 promotes oncogenic transformation by stabilizing Cdc25A. Nat Cell Biol. 2010; 12: 400-6.

48. Carmichael J, Sugars KL, Bao YP, Rubinsztein DC. Glycogen synthase kinase-3 $\beta$ inhibitors prevent cellular polyglutamine toxicity caused by the Huntington's disease mutation. J Biol Chem. 2002; 277: 33791-8.

49. Cross DA, Alessi DR, Cohen P, Andjelkovich M, Hemmings BA. Inhibition of glycogen synthase kinase-3 by insulin mediated by protein kinase B. Nature. 1995; 378: 785-9.

50. Zhao H, Watkins JL, Piwnica-Worms H. Disruption of the checkpoint kinase $1 /$ cell division cycle $25 \mathrm{~A}$ pathway abrogates ionizing radiation-induced S and G2 checkpoints. Proc Natl Acad Sci USA. 2002; 99: 14795-800.

51. Shimuta K, Nakajo N, Uto K, Hayano Y, Okazaki K, Sagata N. Chk1 is activated transiently and targets Cdc25A for degradation at the Xenopus midblastula transition. EMBO J. 2002; 21: 3694-703.

52. Sørensen CS, Syljuåsen RG, Falck J, Schroeder T, Rönnstrand L, Khanna KK, Zhou BB, Bartek J, Lukas J. Chk1 regulates the $S$ phase checkpoint by coupling the physiological turnover and ionizing radiation-induced accelerated proteolysis of Cdc25A. Cancer Cell. 2003; 3: 247-58.

53. Cole KA, Huggins J, Laquaglia M, Hulderman CE, Russell MR, Bosse K, Diskin SJ, Attiyeh EF, Sennett R, Norris G, Laudenslager M, Wood AC, Mayes PA, Jagannathan J, Winter C, Mosse YP, Maris JM. RNAi screen of the protein kinome identifies checkpoint kinase 1 (CHK1) as a therapeutic target in neuroblastoma. Proc Natl Acad Sci USA. 2011; 108: 3336-41.

54. Guo Z, Kumagai A, Wang SX, Dunphy WG. Requirement for Atr in phosphorylation of Chk1 and cell cycle regulation in response to DNA replication blocks and UV-damaged DNA in Xenopus egg extracts. Genes Dev. 2000; 14: 2745 56.

55. Liu Q, Guntuku S, Cui XS, Matsuoka S, Cortez D, Tamai K, Luo G, Carattini-Rivera S, DeMayo F, Bradley A, Donehower LA, Elledge SJ. Chk1 is an essential kinase that is regulated by Atr and required for the G2/M DNA damage checkpoint. Genes Dev. 2000; 14: 1448-59.

56. Zhao H, Piwnica-Worms H. ATR-mediated checkpoint pathways regulate phosphorylation and activation of human Chk1. Mol Cell Biol. 2001; 21: 4129-39.

57. Gatei M, Sloper K, Sorensen C, Syljuäsen R, Falck J, Hobson K, Savage K, Lukas J, Zhou BB, Bartek J, Khanna KK. Ataxia-telangiectasia-mutated (ATM) and NBS1dependent phosphorylation of Chk1 on Ser-317 in response to ionizing radiation. J Biol Chem. 2003; 278: 14806-11. 
58. Hickson I, Zhao Y, Richardson CJ, Green SJ, Martin NM, Orr AI, Reaper PM, Jackson SP, Curtin NJ, Smith GC. Identification and characterization of a novel and specific inhibitor of the ataxia-telangiectasia mutated kinase ATM. Cancer Res. 2004; 64: 9152-9.

59. Sarkaria JN, Busby EC, Tibbetts RS, Roos P, Taya Y, Karnitz LM, Abraham RT. Inhibition of ATM and ATR kinase activities by the radiosensitizing agent, caffeine. Cancer Res. 1999; 59: 4375-82.

60. Blackford AN, Jackson SP. ATM, ATR, and DNA-PK: The Trinity at the Heart of the DNA Damage Response. Mol Cell. 2017; 66: 801-17.

61. McKinnon PJ, Caldecott KW. DNA strand break repair and human genetic disease. Annu Rev Genomics Hum Genet. 2007; 8: 37-55.

62. Zafarullah M, Li WQ, Sylvester J, Ahmad M. Molecular mechanisms of N-acetylcysteine actions. Cell Mol Life Sci. 2003; 60: 6-20.

63. Ciccia A, Elledge SJ. The DNA damage response: making it safe to play with knives. Mol Cell. 2010; 40: 179-204.

64. Szüts D, Krude T. Cell cycle arrest at the initiation step of human chromosomal DNA replication causes DNA damage. J Cell Sci. 2004; 117: 4897-908.

65. Saletta F, Suryo Rahmanto Y, Siafakas AR, Richardson DR. Cellular iron depletion and the mechanisms involved in the iron-dependent regulation of the growth arrest and DNA damage family of genes. J Biol Chem. 2011; 286: 35396-
406.

66. Jin J, Shirogane T, Xu L, Nalepa G, Qin J, Elledge SJ, Harper JW. SCF $\beta$-TRCP links Chk1 signaling to degradation of the Cdc25A protein phosphatase. Genes Dev. 2003; 17: 3062-74.

67. Leung-Pineda V, Ryan CE, Piwnica-Worms $H$. Phosphorylation of Chk1 by ATR is antagonized by a Chk1regulated protein phosphatase $2 \mathrm{~A}$ circuit. Mol Cell Biol. 2006; 26: 7529-38.

68. Yu JS. Activation of protein phosphatase $2 \mathrm{~A}$ by the $\mathrm{Fe} 2+/$ ascorbate system. J Biochem. 1998; 124: 225-30.

69. Luo Y, Liu L, Wu Y, Singh K, Su B, Zhang N, Liu X, Shen Y, Huang S. Rapamycin inhibits mSin1 phosphorylation independently of mTORC1 and mTORC2. Oncotarget. 2015; 6: 4286-98.

70. Gong J, Traganos F, Darzynkiewicz Z. A selective procedure for DNA extraction from apoptotic cells applicable for gel electrophoresis and flow cytometry. Anal Biochem. 1994; 218:314-9.

71. Zhong BZ, Whong WZ, Ong TM. Detection of mineraldust-induced DNA damage in two mammalian cell lines using the alkaline single cell gel/comet assay. Mutat Res. 1997; 393: 181-7. 